\title{
What do we know about stalking?
}

O que sabemos sobre stalking?

¿Qué sabemos sobre el acecho?

Gustavo Cambraia do Canto - https://orcid.org/0000-0002-3586-6969

Alexandre Martins Valença - https://orcid.org/0000-0002-5744-2112

Antônio Geraldo da Silva - https://orcid.org/0000-0003-3423-7076

Bibiana de Borba Telles - https://orcid.org/0000-0002-0398-2412

Alcina Juliana Soares Barros - https://orcid.org/0000-0001-7936-0137

Lisieux Elaine de Borba Telles

- https://orcid.org/0000-0003-4105-

5924

\section{ABSTRACT:}

The term stalking comes from the English language and should be understood as a form of aggression that causes the victim the feeling of being persecuted. The prevalence of victimization by this phenomenon in the community is approximately $11 \%$. Its occurrence is associated with a high potential for impairment of quality of life, psychological and/or physical damage, which may even reach the risk of life and increase the chance of the victim developing mental disorders. Some aggressors meet criteria for psychiatric diagnoses such as personality disorder, bipolar disorder, depression and psychotic disorder, needing attention and adequate psychiatric treatment. Psychiatrists have been involved in this phenomenon in different ways, such as: through the assessment and treatment of patients who are victims of stalking, through the treatment of aggressors or as victims of stalking, to carry out criminal liability 
assessments and risk assessment of the aggressors, act in the judicial demands of victims, as well as in the assessment of the need for breach of professional secrecy. This publication aims to shed light on this phenomenon, so that it is better identified, understood and addressed, and that in the near future, we can make use of effective prevention tools.

Keywords: Forensic Psychiatry; Penal Code; Stalking; Mental Disorders.

\section{RESUMO:}

O termo stalking vem da língua inglesa e deve ser entendido como uma forma de agressão que provoca na vítima a sensação de estar sendo perseguida. A prevalência de vitimização por esse fenômeno na comunidade é de aproximadamente $11 \%$. Sua ocorrência está associada a um alto potencial de comprometimento da qualidade de vida, danos psicológicos e/ou físicos, podendo inclusive atingir o risco de vida e aumentar a chance de a vítima desenvolver transtornos mentais. Alguns agressores atendem a critérios para diagnósticos psiquiátricos, como transtorno de personalidade, transtorno bipolar, depressão e transtorno psicótico, necessitando de atenção e tratamento psiquiátrico adequado. Os psiquiatras têm estado envolvidos neste fenômeno de diferentes formas, tais como: através da avaliação e tratamento de pacientes vítimas de perseguição, através do tratamento de agressores ou como vítimas de perseguição, para a avaliação de responsabilidade penal e avaliação de risco dos agressores, atuar nas demandas judiciais das vítimas, bem como na avaliação da necessidade de violação do segredo profissional. Esta publicação tem como objetivo lançar luz sobre este fenômeno, para que seja melhor identificado, compreendido e abordado, e que num futuro próximo possamos lançar mão de ferramentas eficazes de prevenção.

Palavras chave: Psiquiatria Forense; Código Penal; Perseguição; Transtornos Mentais, Desordem Mental.

\section{RESUMEN:}

El término acecho proviene del idioma inglés y debe entenderse como una forma de agresión que provoca en la víctima la sensación de ser perseguida. La prevalencia de victimización por este fenómeno en la comunidad es aproximadamente del $11 \%$. Su ocurrencia está asociada a un alto potencial de deterioro de la calidad de vida, daño psicológico y / o 
físico, que puede llegar incluso al riesgo de vida y aumentar la probabilidad de que la víctima desarrolle trastornos mentales. Algunos agresores cumplen criterios para diagnósticos psiquiátricos como trastorno de personalidad, trastorno bipolar, depresión y trastorno psicótico, por lo que necesitan atención y tratamiento psiquiátrico adecuado. Los psiquiatras se han involucrado en este fenómeno de diferentes formas, tales como: a través de la valoración y tratamiento de los pacientes víctimas de acecho, a través del tratamiento de agresores o como víctimas de acecho, para realizar valoraciones de responsabilidad penal y valoración de riesgo de los agresores, actuar en las demandas judiciales de las víctimas, así como en la valoración de la necesidad de violación del secreto profesional. Esta publicación tiene como objetivo arrojar luz sobre este fenómeno, para que sea mejor identificado, comprendido y abordado, y que en un futuro próximo podamos hacer uso de herramientas de prevención eficaces.

Palabras clave: Psiquiatría forense; Código Penal; Acecho; Desordenes mentales.

How to cite: Canto GC, Valença AM, Silva AG, Telles BB, Barros AJ, Telles LEB - What do we know about stalking? Debates em Psiquiatria, Rio de Janeiro, 2021; 11:1-7. https://doi.org/10.25118/27639037.2021.v11.274

Disclosure of potential conflicts of interest: none

Funding: none

Approval Research Ethics Committee (REC): none

Received on: $17 / 12 / 2021$

Accepted on: 20/12/2021

Published on: 29/12/2021 


\section{Introduction}

The term stalking comes from the English language and should be understood as a form of aggression that causes the victim the feeling of being persecuted.

By definition, stalking is reiterated harassment, which can take different forms [1] , such as: repeatedly calling the victim; sending unwanted gifts to the victim's workplace or home; sending correspondence with inappropriate and embarrassing content; staying physically close and noticeable, without coming into direct contact; making direct contact, intercepting the victim in an inappropriate or threatening way; spreading false rumors about the victim; causing property damage (furniture, automobiles, pets); stalking the individual in apps, repeatedly sending emails (cyberstalking); threatening, causing direct physical damage and even killing.

The prevalence of victimization by this phenomenon in the community is approximately $11 \%$ []ㅡ (being up to four times more frequent in the female population). Its occurrence is associated with a high potential for impairment of quality of life, psychological and/or physical damage, which may even reach the risk of life and increase the chance of the victim developing mental disorders [1]. The intensity and frequency of harassment actions can influence the impact on the victim [2] ]. In addition, it is important to consider the economic and social impact that these situations cause on the victim, with a reduction in working hours, giving up employment, restriction of social life and security expenses.

To face this reality, in March 2021, Law 14.132/2021 []ㅡ] was approved by the National Congress, which included Article 147-A in the Brazilian Penal Code and stipulated a specific penalty for the act of reiterated harassment of other people by any means, which consists of a prison term of up to two years, which may be extended in the presence of aggravating factors. The new law has been popularly called the "anti-stalking law" and has brought national visibility to this behavior, which will facilitate the identification of these actions and the proper referral of aggressors and victims, whether at the judicial or health level. The described law revoked Article 65 of the Criminal Misdemeanor Law, which provided for the situation of "molesting or disturbing the tranquility", and proposed the penalty of imprisonment from 15 days to two months. The new law establishes a stricter punishment 
for a form of harassment that is repetitive, which is a characteristic of persecution.

Although it is a form of aggression that is still little studied within the scientific community, psychiatrists have been involved in this phenomenon in different ways, such as: through the assessment and treatment of patients who are victims of stalking, through the treatment of aggressors or as victims of stalking [4]. In addition, within the field of forensic psychiatry, when the crime of harassment is configured, the professional may be called to carry out criminal liability assessments and risk assessment of the aggressors, act in the judicial demands of victims, as well as in the assessment of the need for breach of professional secrecy.

\section{Profile of aggressors and victims}

The victims are mostly women of a young age. The high prevalence of this phenomenon among mental health professionals who provide services to the aggressor is highlighted. A British study found a 35\% prevalence of stalking victimization among psychiatrists [4].

Men account for approximately $80 \%$ of the aggressors, and frequently, the persecution involves explicit threats and physical aggression, with recurrence being frequent $-49 \%$ of the aggressors recur (of these, $80 \%$ within 1 year) [ㅁ].

It is important to emphasize that the aggressor's objective can be different. Among the most common are: search for greater intimacy with the victim; reconciliation; punishment or revenge; the need for control; sexual predation. There are different ways to classify stalking, and adopting typography can make it easier to understand the risk added to a specific modus operandi.

Some aggressors meet criteria for psychiatric diagnoses such as personality disorder, bipolar disorder, depression and psychotic disorder, needing attention and adequate psychiatric treatment. In the presence of doubt about the aggressor's mental health, the judge can determine the Assessment of Criminal Imputability of this, where in addition to the presence of a mental disorder, the forensic psychiatrist must assess the aggressor's ability to understand and determine the time of the facts.

The forensic psychiatrist, when evaluating the risk factors for this type of violence and its possible recurrence, should be aware of the following 
predictors []ㅡ: history of the previous intimate relationship between aggressor and victim, age under 30 years, low education, history of previous aggressions, threats, use of psychoactive substances and the aggressor's suicidality.

This publication aims to shed light on this phenomenon, so that it is better identified, understood and addressed, and that in the near future, we can make use of effective prevention tools.

\section{References}

1. Mester R, Birger M, Margolin J. Stalking. Isr J Psychiatry Relat Sci. 2006;43(2):102-11. https://cdn.doctorsonly.co.il/2011/12/2006 2 6.pdf

2. Dreßing $H$, Gass $P$, Schultz K, Kuehner $C$ : The prevalence and effects of stalking: a replication study. Dtsch Arztebl Int 2020; 117: 347-53. https://doi.org/10.3238/arztebl.2020.0347 PMid:32657747 - PMCid:PMC7373813

3. Brasil. Lei 14.132/2021 - Crime de perseguição http://www.planalto.gov.br/ccivil 03/Ato20192022/2021/Lei/L141 32.htm

4. Whyte S, Penny C, Christopherson S, Reiss D, Petch E. The stalking of psychiatrists. Int J Forensic Ment Health 2011;10:254-60 https://doi.org/10.1080/14999013.2011.599097

5. Rosenfeld B. Recidivism in stalking and obsessional harassment. Law Hum Behav. 2003 Jun;27(3):251-65.

https://doi.org/10.1023/A:1023479706822 - PMid:12794963

6. Rosenfeld, B, Harmon, R. (2002). Factors Associated with Violence in Stalking and Obsessional Harassment Cases. Criminal Justice and Behavior, 29(6), 671-691.

https://doi.org/10.1177/009385402237998 


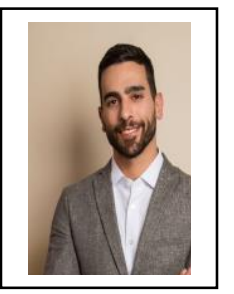

Gustavo Cambraia do Canto

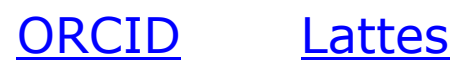

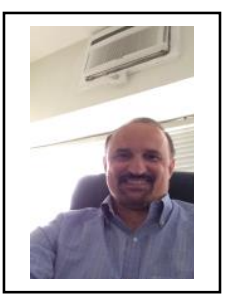

Alexandre Martins Valença

$\underline{\text { ORCID } \quad \text { Lattes }}$

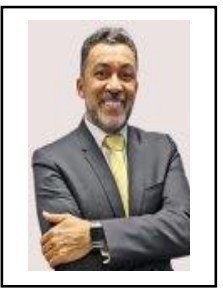

Antônio Geraldo da Silva

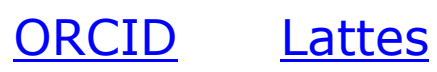

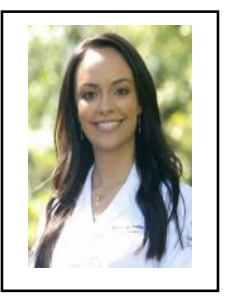

Bibiana de Borba Telles

ORCID Lattes

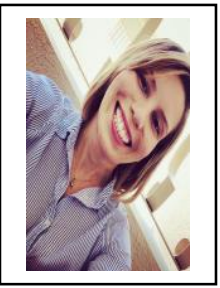

Alcina Juliana Soares Barros

$\underline{\text { ORCID }}$

Lattes

Lisieux Elaine de Borba Telles ORCID Lattes 